\title{
Pengembangan Multimedia Pembelajaran Matematika Model Tutorial Berbasis Problem Based Learning pada Materi Aritmatika Sosial untuk Siswa SMP/MTs
}

\author{
Bj. Nofrian Kurnia ${ }^{1}$, Jefri Marzal ${ }^{2}$, Zurweni ${ }^{3}$ \\ 1, 2 Program Magister Pendidikan Matematika, FMIPA Universitas Negeri Jambi, \\ Jl. Raden Mattaher No.16-Jambi, Kota Jambi, Indonesia \\ Rian_v96@yahoo.com
}

\begin{abstract}
Social arithmetic is one of the subjects studied at the SMP/MTS level. The subject of arithmetic will provide benefits for students when solving problems in everyday life in the future. Despite the importance of the material to be learned, most students still have difficulty in solving problems related to social arithmetic material, for that we need a multimedia learning mathematics tutorial model based on Problem Based Learning. This study aims to see how the process and results of the development of multimedia learning mathematics and to determine the validity, practicality, and effectiveness of multimedia learning mathematics produced using a tutorial model and based on Problem Based Learning on arithmetic material. procedures according to Lee \& Owens, namely assessment/Analysis, design, development, implementation, and evaluation. The results obtained, namely the Learning Multimedia product developed according to Lee \& Owens is declared valid, practical, and effective, this is based on the results of the pretest and posttest data analysis of students with a gain test of 0.536 in moderate criteria. It can be concluded that the developed mathematics learning multimedia is very good so that the learning multimedia is effective for use by teachers and students in learning about social arithmetic material.
\end{abstract}

Keywords: Multimedia Learning Mathematics, Problem Based Learning, Social Arithmetic

\begin{abstract}
Abstrak
Aritmatika sosial adalah salah satu pokok bahasan yang dipelajari ditingkat SMP/MTS. Pokok bahasan aritmatika tersebut akan memberikan manfaat bagi siswa pada saat menyelesaikan permasalahan dalam kehidupan sehari-hari pada masa yang akan datang. Walaupun pentingnya materi tersebut untuk dipelajari namun kebanyakan siswa masih mengalami kesulitan dalam menyelesaikan permasalahan yang berhubungan dengan materi aritmatika sosial, untuk itu diperlukan multimedia pembelajaran matematika model tutorial berbasis Problem Based Learning. Penelitian ini bertujuan untuk melihat bagaimana proses dan hasil dari pengembangan multimedia pembelajaran matematika serta mengetahui kevalidan, kepraktisan, dan keefektifan multimedia pembelajaran matematika yang dihasilkan menggunakan model tutorial dan berbasis Problem Based Learning pada materi aritmatika Penelitian ini merupakan penelitian Research and Development (R\&D) dengan menggunakan prosedur menurut Lee \& Owens, yaitu assessment/Analysis, design, development, implementation dan evaluation. Hasil penelitian yang diperoleh yaitu produk Multimedia Pembelajaran yang dikembangkan menurut Lee \& Owens dinyatakan valid, praktis, dan efektif, hal ini berdasarkan hasil analisis data pretest dan posttest peserta didik dengan uji gain sebesar 0,536 dalam kriteria sedang. Dapat disimpulkan bahwa multimedia pembelajaran matematika yang dikembangkan sangat baik sehingga multimedia pembelajaran efektif untuk digunakan oleh guru dan peserta didik dalam pembelajaran pada materi aritmatika sosial.
\end{abstract}

Kata kunci: Multimedia pembelajaran matematika, Problem Based, Learning, Aritmatika Sosial

Copyright (c) 2022 Bj. Nofrian Kurnia, Jefri Marzal, Zurweni

$\square$ Corresponding author: $\mathrm{Bj}$. Nofrian Kurnia

Email Address: Rian_v96@yahoo.com (Jl. Raden Mattaher No.16-Jambi, Kota Jambi, Indonesia)

Received 01 January 2022, Accepted 15 February 2022, Published 16 February 2022

\section{PENDAHULUAN}

Aritmatika sosial adalah salah satu pokok bahasan yang dipelajari di tingkat SMP/MTS. Aritmatika sosial adalah ilmu yang membahas transaksi ekonomi dalam kehidupan sehari-hari yang dipecahkan dengan aplikasi aritmatika Nurnugroho, B. A., Supama, S., \& Zulijanto (2019) materi yang dipelajari meliputi harga penjualan, harga pembelian, keuntungan, kerugian, bunga, diskon. 
Pokok bahasan aritmatika tersebut akan memberikan manfaat bagi siswa pada saat menyelesaikan permasalahan dalam kehidupan sehari-hari pada masa yang akan datang. Walaupun pentingnya materi tersebut untuk dipelajari namun kebanyakan siswa masih mengalami kesulitan dalam menyelesaikan permasalahan yang berhubungan dengan materi aritmatika sosial.

Berdasarkan wawancara peneliti dengan salah satu guru matematika berinisial SO di SMP Negeri 1 Muaro Jambi beliau mengungkapkan bahwa sebagian siswa kurang aktif dan kemampuan memahami aritmatika sosial siswa rendah, karena dari total keseluruhan siswa di kelas hanya sebagian yang memahami aritmatika sosial dengan kategori baik dan pada saat pembelajaran dikelas hanya terdapat beberapa siswa yang aktif dan mau menanggapi pertanyaan dari guru dan mau bertanya apabila menemui kesulitan dalam mengerjakan soal.

Kemudian berdasarkan pengamatan yang peneliti lakukan terlihat bahwa kemampuan siswa dalam menyelesaikan soal-soal yang berkaitan dengan aritmatika sosial masih rendah. Hal ini ditandai dengan siswa belum mampu menyelesaikan soal-soal pada soal berbentuk cerita, siswa belum bisa menceritakan kembali soal dengan bahasa semdiri, siswa belum memahami konsep sehingga salah dalam menentukan rumus yang akan digunakan, masih salah dalam melakukan perhitungan, dan siswa tidak menarik kesimpulan dari hasil jawabannya. Kondisi diatas terjadi karena dalam pembelajaran konvensional siswa jarang sekali diminta untuk aktif, siswa cenderung pasif dalam pembelajaran, dimana siswa lebih banyak mengamati, mencatat dan mendengarkan penjelasan guru.

Berdasarkan wawancara peneliti dengan beberapa siswa diketahui bahwa siswa mengalami kesulitan untuk menyelesaikan soal-soal tentang aritmatika sosial yang diberikan oleh guru. Peserta didik berinisial NPS mengungkapkan bahwa meskipun disekolah sudah dilengkapi dengan fasilitas yang mendukung namun guru jarang sejali menggunakan media dalam pembelajaran, belajar dikelas rata-rata hanya menghafal, tanpa mengenali dan mengalami langsung materi yang dipelajari. Guru langsung menjelaskan topik yang akan dipelajari, dilanjutkan dengan pemberian contoh soal dan soal untuk latihan. Hal ini membuat siswa apabila ditanya suatu konsep atau proses siswa tidak bisa menjawab dengan penuh keyakinan atau lebih memilih diam.

Hasil penelitian Dila \& Zanthy (2020) adapun kesulitan siswa pada saat menjawab soal aritmatika sosial dibagi tiga aspek, yaitu: (1) kesulitan siswa pada aspek bahasa sebesar 50\%, yaitu sulit memahami atau menafsirkan soal dan tidak dapat menceritakan kembali dengan bahasa sendiri; (2) kesulitan siswa pada aspek prasyarat sebesar 75\%, yaitu berkaitan dengan aspek bahasa sehingga siswa tidak menuliskan apa yang diketahui dan ditanyakan, kurang memahami konsep, dan menentukan rumus; dan (3) kesulitan siswa pada aspek terapan sebesar 50\%, yaitu kesulitan melakukan proses perhitungan sehingga siswa tidak menarik kesimpulan dari jawaban soal tersebut. Selain kesulitan siswa dalam menyelesaikan soal aritmatika sosial, penyebab dari kesulitan itu terjadi karena siswa tidak paham dengan materi aritmatika tersebut. Dikarenakan pada saat belajar siswa tidak memperhatikan guru atau guru pada saat memberikan penjelasan pendekatan yang digunakan dikelas kurang maksimal. 
Beberapa cara untuk dapat meningkatkan pemahaman siswa tentang aritmatika sosial, salah satunya penelitian Istikomah (2020) dengan judul model Problem Based Learning untuk meningkatkan hasil belajar matematika pada materi aritmatika sosial. Adapun hasil yang diperoleh yaitu persentase rata-rata keseluruhan aktivitas siswa pada siklus I ke siklus 2 sebesar 33,33\%, dimana pada siklus pertama ini hanya 6 siswa atau 50\% dari 12 siswa yang tuntas dan pada siklus II mengalami peningkatan sebesar 33,33\% atau 10 siswa yang tuntas sehingga meningkat menjadi 83,33\% termasuk kualifikasi baik. Dari penelitian diperoleh kesimpulan bahwa model pembelajaran Problem Based Learning dapat meningkatkan hasil belajar siswa pada materi aritmatika sosial.

Jika ditinjau dari media pembelajaran yang digunakan, SMP Negeri 1 Muaro Jambi juga telah menggunakan media, seperti media visual dua dimensi tidak transparan (grafik, chart/bagan, peta, diagram, poster) kelemahan dari media visual tidak transparan adalah media tersebut disajikan tidak bergerak sehingga daya tariknya tidak sekuat multimedia, media visual dua dimensi transparan (film, Overhead projector, film strip, micro film) kelemahan dari media visual dua dimensi transparan diantaranya adalah tidak cocok digunakan bagi orang yang memiliki kelainan pada penglihatan, media visual tiga dimensi (benda sesungguhnya, model, specimen, diorama) kelemahan media visual tiga dimensi adalah media tidak dapat disajikan dalam buku (tulisan), media audio (radio, audio tape recorder, alat music modern/tradisional, cd player) kelemahan dari media audio adalah tidak semua orang bisa mendengarnya jika memiliki kelainan pada pendengarannya,

Agar siswa dapat memahami materi yang diberikan maka pembelajaran matematika harus dibuat menarik, sehingga pembelajaran menjadi bermakna dengan adanya umpan balik dari siswa. Sehingga dibutuhkan media pembelajaran yang menarik minat siswa untuk terlibat dalam pembelajaran. Berdasarkan pemaparan sebelumnya, maka peneliti ingin mengembangkan sebuah media pembelajaran khusus mata pelajaran aritmatika sosial yang berbentuk multimedia pembelajaran matematika model tutorial berbasis Problem Based Learning dan dioperasikan pada perangkat komputer.

\section{METODE}

Model pengembangan yang digunakan dalam penelitian ini yaitu model penelitian dan pengembangan (Research \& Development) yang dikemukakan oleh Lee, W. W., \& Owens (2004). Penelitian ini menggunakan model pengembangan yang diadaptasi dari model ADDIE yang dikembangkan oleh Lee dan Owens. Prosedur penelitian dan pengembangan dalam model Lee, W. W., \& Owens (2004:3) terdiri dari lima tahap, yaitu (1) Penilaian/analisis (assessment/analysis) yang meliputi analisis kebutuhan (need assessment) dan analisis awal akhir (front-end analysis), (2) desain (design), (3) pengembangan (development), (4) implementasi (implementation), dan (5) evaluasi (evaluation). Untuk lebih jelasnya langkah-langkah tersebut dimuat dalam Gambar 1. 


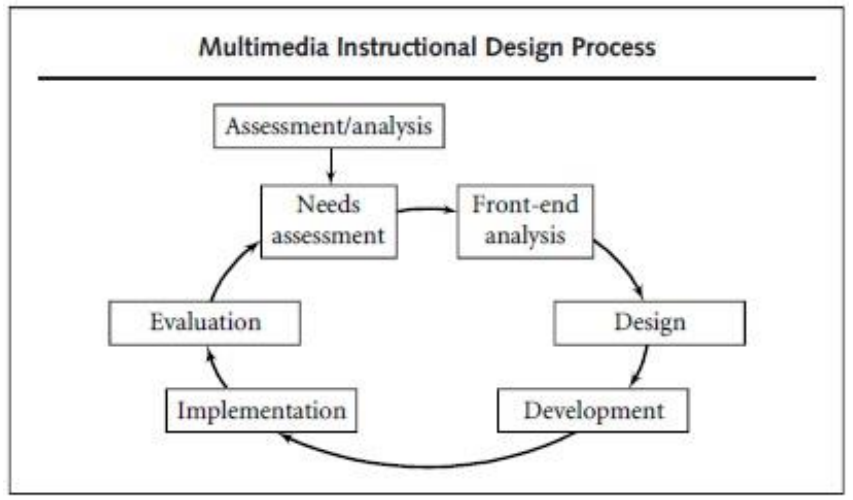

Gambar 1. Pengembangan Model Lee, W. W., \& Owens (2004:3)

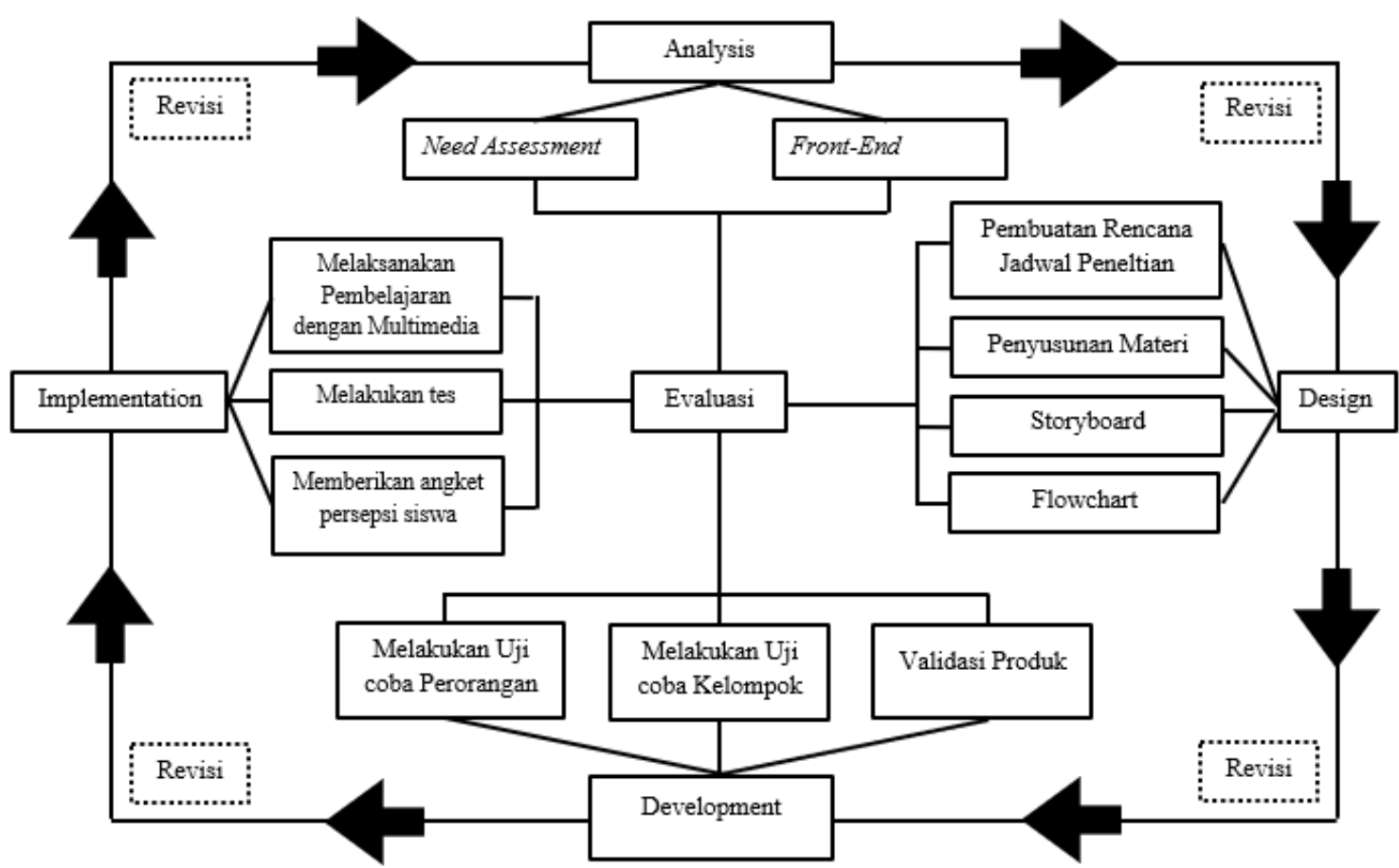

Gambar 2. Prosedur Pengembangan Model Lee, W. W., \& Owens (2004)

Uji coba produk multimedia pembelajaran matematika berbasis Problem Based Learningg dilaksanakan di SMPN 1 Muaro Jambi. Subjek uji coba penelitian ini adalah siswa kelas VIIA SMP N 1 Muaro Jambi dan objek dalam penelitian ini adalah multimedia pembelajaran matematika model tutorial berbasis Problem Based Learningg pada materi aritmatika sosial untuk siswa SMP/MTS.

\section{Instrumen Pengumpulan Data}

Instrumen pengumpulan data berupa lembar observasi, lembar wawancara, lembar validasi media, lembar validasi materi, angket respon guru, angket respon siswa, lembar tes soal. Tes evaluasi tertulis yang dilaksanakan kepada siswa berguna untuk mengetahui hasil belajar siswa setelah belajar menggunakan multimedia pembelajaran matematika model tutorial berbasis Problem Based Learning. 


\section{Teknik Analisis Data}

Analisis data penelitian ini dilakukan untuk mengetahui apakah multimedia pembelajaran yang dikembangkan sudah memenuhi kriteria yang di harapkan yaitu multimedia harus valid, praktis dan efektif. Kevalidan diperoleh dari data hasil angket yang diberikan kepada tim ahli, kepraktisan dan keefektifan diperoleh setelah produk diterapkan dilapangan.

Analisis kevalidan multimedia pembelajaran model tutorial berupa angket yang digunakan untuk mendapatkan kevalidan dari multimedia yang dikembangkan. Setelah data dari penyebaran angket didapatkan dari tim validator, penilaian pendidik dan peserta didik berupa tanggapan, saran, dan komentar terhadap multimedia pembelajaran yang dikembangkan, langkah selanjutnya adalah dengan membuat deskripsi hasil tanggapan, saran, dan komentar yang diperoleh dari tim validator, penilaian pendidik dan peserta didik tersebut. Untuk menganalisis angket penilaian guru pada multimedia pembelajaran matematika model tutorial digunakan skala Likert. Data analisis angket siswa dapat dilihat dari angket yang telah diisi siswa. Angket tersebut disusun dalam bentuk skala Likert. Untuk menganalisis angket respon pada multimedia pembelajaran matematika model tutorial digunakan skala Likert

Setelah produk yang telah divalidasi dan diterapkan dalam pembelajaran, kemudian peserta didik mengikuti tes akhir (posttest) yang akan dibandingkan dengan hasil tes awal (pre-test) yang telah diadakan sebelum penggunaan multimedia pembelajaran digunakan. Tes ini bertujuan untuk mengukur keefektifan belajar dengan mengetahui besarnya peningkatan yang terjadi setelah penggunaan multimedia pembelajaran matematika model tutorial berbasis Problem Based Learning. Data hasil pre-test dan post-test dicari berapa nilai rata-ratanya, dan akan dilakukan uji normalitas, uji homogenitas, uji $\mathrm{N}$-gain dan uji paired $t$-tes.

\section{HASIL DAN DISKUSI}

\section{Hasil Analisis Pendahuluan}

Penilaian kebutuhan adalah proses sistematis untuk menentukan tujuan, mengidentifikasi perbedaan antara kondisi aktual dan yang diinginkan, dan menetapkan prioritas tindakan Lee \& Roadman dalam Lee, W. W., \& Owens (2004). Langkah pertama adalah menentukan kondisi sebenarnya disekolah dengan melakukan wawancara kepada guru matematika untuk mengetahui produk yang sesuai dengan peserta didik, tujuan pembelajaran, kompetensi inti, kompetensi dasar serta mengetahui materi-materi apa saja yang ada pada pelajaran matematika khususnya kelas VII pada semester genap.

Berdasarkan analisis ini diperoleh informasi bahwa SMP Negeri 1 Muaro Jambi telah menerapkan kurikulum 2013 dan pendekatan yang digunakan dalam pembelajaran pada umumnya adalah pendekatan ilmiah. Selanjutnya melakukan observasi di SMP Negeri 1 Muaro Jambi dengan tujuan untuk mengetahui masalah yang ada sehingga menyebabkan kondisi yang diharapkan tidak 
terjadi. Observasi dilakukan dengan memberikan lembar observasi kepada guru matematika yang mengajar di kelas VII sekolah tersebut. Data dari kegiatan observasi yaitu:

1. Penyampaian materi secara teori oleh guru sudah bagus, namun peserta didik kurang aktif karena pembelajaran terlalu berpusat pada guru.

2. Media pembelajaran yang kurang bervariasi sehingga membuat siswa mudah bosan.

3. Siswa memerlukan media pembelajaran yang dapat digunakan dimanapun dan kapanpun siswa belajar.

4. Belum adanya media pembelajaran model tutorial dalam proses pembelajaran pada mata pelajaran Aritmatika Sosial.

Berdasarkan dari hasil kegiatan observasi, akan dilakukan pengembangan multimedia pembelajaran matematika model tutorial berbasis Problem Based Learning sebagai sarana belajar siswa Kelas VII di SMP Negeri 1 Muaro Jambi. Karena kondisi yang diharapkan tidak terjadi atau terjadi kesenjangan kinerja sehingga perlu dilanjutkan dengan menetapkan tujuan dengan berdasarkan kesenjangan dengan kondisi nyata dan kondisi ideal yang diharapkan.

\section{Design}

\section{Penyusunan Materi}

Materi disusun berdasarkan tahapan-tahapan dari model Problem Based Learning, (1) orientasi peserta didik pada masalah, (2) Mengorganisasikan peserta didik untuk belajar, (3) membantu menyelidiki secara mandiri atau kelompok, (4) mengembangkan dan mempresentasikan hasil kerja, dan (5) menganalisis dan mengevaluasi proses mengatasi masalah.

\section{Pembuatan Storyboard}

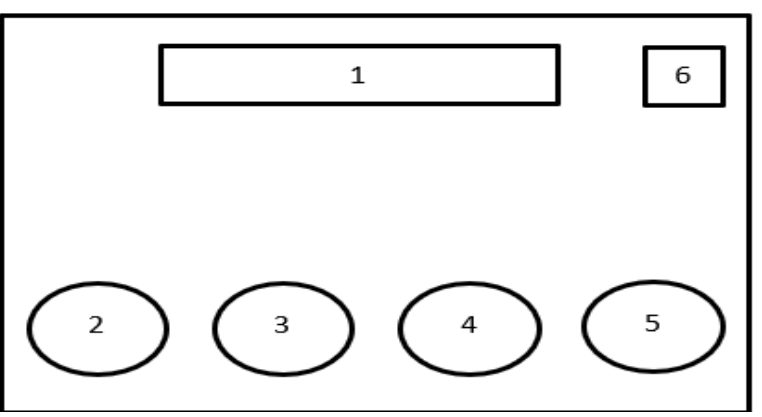

\begin{tabular}{|ll|}
\hline \multicolumn{2}{|l|}{ Halaman menu utama } \\
1. & Judul \\
2. & Tombol KI dan KD \\
3. & Tombol Materi \\
4. & Tombol Evaluasi \\
5. Tombol Informasi \\
6. Tombol exit
\end{tabular}

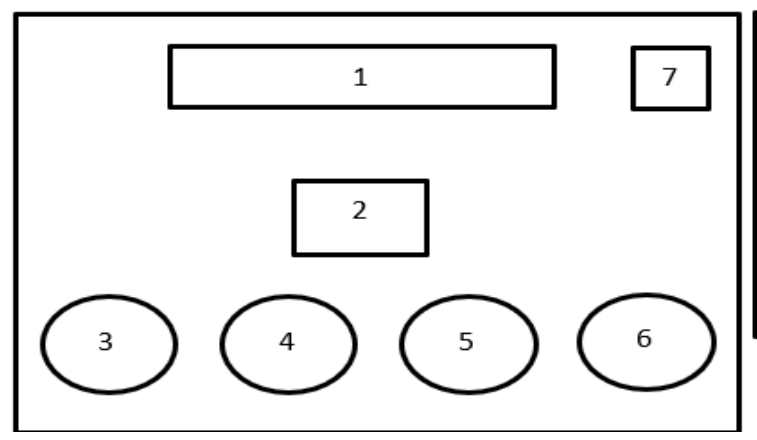

$$
\begin{array}{ll}
\hline \text { 1. } & \text { Halaman materi } \\
\text { 2. } & \text { Tombol pendahuluan } \\
\text { 3. Tombol KI/KD } \\
\text { 4. Tombol Materi } \\
\text { 5. Tombol Evaluasi } \\
\text { 6. Tombol Informasi } \\
\text { 7. Tombol exit }
\end{array}
$$

Gambar 1. Cuplikan Storyboard 


\section{Pembuatan Flowchart}

Dengan adanya Flowchart urutan proses kegiatan menjadi lebih jelas. Jika ada penambahan proses maka dapat dilakukan dengan lebih mudah. Setelah Flowchart selesai disusun, selanjutnya akan diterjemahkan kebentuk program dengan bahasa pemrograman dalam hal ini adalah multimedia pembelajaran model tutorial berbasis Problem Based Learning. Berikut tampilan dari flowchart multimedia pembelajaran model tutorial berbasis Problem Based Learning.

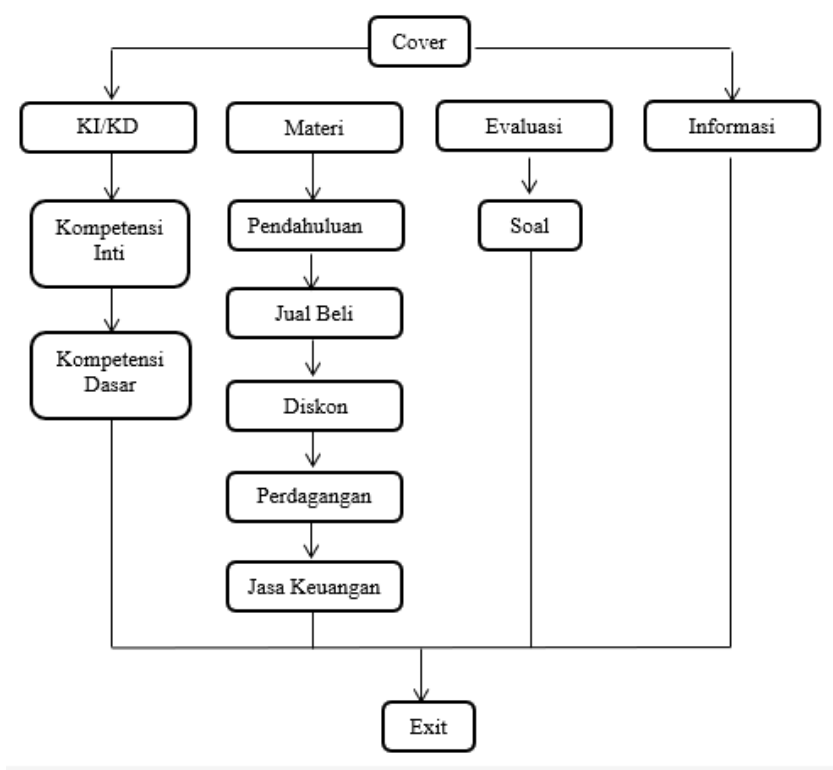

Gambar 2. Flowchart

\section{Development}

Tahap pengembangan dilaksanakan untuk memperoleh produk berupa multimedia pembelajaran matematika model tutorial berbasis Problem Based Learning pada materi aritmatika sosial dikembangkan dan disempurnakan agar menjadi produk yang utuh dan bagus.

\section{Validasi Ahli Materi}

Pada validasi materi dilakukan oleh Bapak Dr.Drs. Syaiful, M.Pd terhadap multimedia dengan mengisi angket yang ditujukan untuk menguji kualitas isi dan tujuan serta kualitas instruksional dengan 25 pertanyaan. Berdasarkan hasil penilaian ahli materi seperti pada lampiran 6, diperoleh hasil bahwa pada setiap pernyataan yang diberikan, menurut Bapak Dr. Drs. Syaiful, M.Pd sebagai ahli materi bahwa materi pembelajaran sudah sesuai dengan aspek yang ingin dicapai yaitu aspek kualitas isi, tujuan, dan kualitas instruksional.

Pembelajaran menggunakan model Problem Based Learning dengan sintaks orientasi peserta didik pada masalah, dimana pada tahap ini guru membahas tujuan pembelajaran, mendeskripsikan dan memotivasi peserta didik agar terlibat dalam kegiatan mengatasi masalah yang ada, pada tahap mengorganisasikan peserta didik untuk belajar Guru membantu anak didik untuk mendefinisikan dan mengorganisasikan tugas-tugas belajar yang terkait dengan permasalahannya, pada tahap Membantu menyelediki secara mandiri atau kelompok Guru mendorong peserta didik untuk mendapatkan 
informasi yang tepat, melakukan eksperimen dan mencari penjelasan serta solusi untuk penyelesaian masalah tersebut, pada tahap Mengembangkan dan mempresentasikan hasil kerja Guru membantu peserta didik dalam merencanakan dan menyiapkan hasil-hasil yang tepat, seperti laporan, rekaman video dan model-model yang membantu mereka untuk menyampaikan kepada orang lain hasil yang mereka dapatkan untuk menyelesaikan masalah tersebut, pada tahap Menganalisis dan mengevaluasi proses mengatasi masalah Guru membantu anak didik untuk melakukan refleksi terhadap investigasinya dan proses-proses yang mereka gunakan. Berdasarkan tanggapan yang telah diberikan oleh Bapak Dr.Drs. Syaiful, M.Pd bahwa keseluruhan materi pembelajaran sudah sesuai dan dinyatakan layak untuk uji coba lapangan tanpa revisi

\section{Validasi Ahli Desain Media}

Selanjutnya, hasil validasi desain pembelajaran oleh Bapak Drs. Haryanto, M.Pd. sudah cukup baik, namun ada sedikit perbaikan terhadap Multimedia yang telah dibuat dengan kisi-kisi validasi desain pembelajaran multimedia pembelajaran matematika yang akan diuji yaitu multimedia pembelajaran model tutorial dan model Problem Based Learning dengan 18 indikator dan 18 pertanyaan, dengan hasil bahwa setiap pernyataan yang diberikan oleh ahli desain multimedia memberikan tanggapan yang cukup baik terhadap keseluruhan aspek penilaian desain multimedia yang dikembangkan dan dinyatakan layak untuk ujicoba lapangan dengan revisi.

\section{Evaluasi Formatif}

Langkah yang umum dilakukan pada tahap ini yaitu uji coba perorangan, uji coba kelompok kecil dan uji coba kelompok besar (Branch 2009:123). Uji coba perorangan dilakukan penilaian oleh guru matematika yang mengajar di kelas VII SMP Negeri 1 Muaro Jambi. Tujuan dari penilaian guru adalah untuk mengetahui pendapat dan masukan awal untuk Multimedia Pembelajaran yang telah dikembangkan. Penilaian guru diminta kepada guru yang mengajar matematika dengan inisial Sri Oktavia S.Pd untuk mengamati dan menilai Multimedia pembelajaran secara keseluruhan. Setelah itu peneliti memberikan angket untuk memberikan penilaian. Angket terdiri dari 20 pertanyaan dengan 3 aspek, yaitu kemenarikan, mudah digunakan, dan kualitas isi. Penilaian dan saran dari guru tersebut peneliti jadikan sebagai pedoman untuk melakukan perbaikan kembali terhadap multimedia pembelajaran yang telah dikembangkan agar sesuai dengan kebutuhan peserta didik serta dapat meningkatkan kemampuan matematis peserta didik. Secara umum penilaian guru terhadap multimedia yang dikembangkan sangat positif, namun terdapat saran yang diberikan oleh subjek agar multimedia pembelajaran yang dikembangkan bisa menjadi lebih baik.

Uji coba yang dilakukan setelah uji coba perorangan adalah uji coba kelompok kecil. Uji coba ini dilakukan di kelas VIIB SMP Negeri 1 Muaro Jambi dengan jumlah peserta didik sebanyak 8 siswa yang berkemampuan rendah, sedang, dan tinggi yang diketahui berdasarkan informasi dari guru matematika yang mengajar di kelas tersebut. Tiap-tiap peserta diberikan Multimedia pembelajaran yang sudah peneliti kembangkan. Uji coba produk ini berlangsung selama 2 jam pelajaran dengan memberikan gambaran umum mengenai materi, kegiatan-kegiatan peserta didik dalam multimedia 
pembelajaran matematika model tutorial berbasis Problem Based Learning dalam multimedia pembelajaran. Selanjutnya peserta didik diminta untuk mengamati multimedia pembelajaran secara menyeluruh dan memberikan penilaian berupa tanggapan peserta didik terhadap multimedia pembelajaran yang dikembangkan. Sebelum memberikan penilaian menggunakan angket, peneliti menjelaskan kepada peserta mengenai cara pengisian dan penjelasan terhadap tiap-tiap pernyataan pada angket. Hasil uji coba diperoleh tanggapan positif terhadap prototipe dan mereka tertarik belajar menggunakan multimedia pembelajaran dengan model tutorial sebagai sumber belajarnya.

Setelah uji coba kelompok kecil, dilanjutkan dengan uji coba kelompok besar. Uji coba ini melibatkan 36 orang peserta didik di kelas VIIA SMP Negeri 1 Muaro Jambi. Uji coba ini berlangsung selama kurang lebih 2 jam pelajaran dengan memberikan gambaran umum mengenai materi pelajaran, kegiatan-kegiatan pembelajaran dalam Multimedia pembelajaran, dan aplikasi multimedia pembelajaran dalam proses pembelajaran. Setelah semua peserta uji coba kelompok besar mengamati multimedia pembelajaran, dilanjutkan dengan memberikan penilaian berupa tanggapan peserta didik terhadap multimedia pembelajaran yang akan digunakan. Penilaian dari peserta didik diperoleh dari angket untuk mengetahui persepsi peserta didik mengenai multimedia pembelajaran yang dikembangkan. Sebelum memberikan penilaian menggunakan angket, peneliti menjelaskan kepada peserta mengenai cara pengisian dan menjelaskan maksud tiap-tiap pernyataan pada angket. Kemudian masing-masing peserta uji coba kelompok besar mengisi angket tersebut sesuai dengan pemahaman dan penilaian masing-masing.

\section{Implementation}

Implementasi dilakukan atau diterapkan dalam situasi kelas yang sebenarnya dengan pengajaran yang sesungguhnya dengan menggunakan multimedia pembelajaran matematika model tutorial berbasis Problem Based Learning pada materi aritmatika sosial yang melibatkan subjek satu kelas yaitu kelas VII SMP Negeri 1 Muaro Jambi

Pada tahap implementasi, produk yang telah di uji coba diterapkan dalam situasi kelas yang sebenarnya dengan pengajaran yang sesungguhnya menggunakan multimedia pembelajaran matematika model tutorial berbasis Problem Based Learning yang melibatkan subjek sebanyak 36 siswa di kelas VIIA SMP Negeri 1 Muaro Jambi. Kegiatan pembelajaran dilaksanakan selama 4 kali pertemuan. Tiap-tiap pertemuan pada pembelajaran ini dilaksanakan dalam tiga kegiatan, yaitu pendahuluan, kegiatan inti, dan kegiatan penutup. Masing-masing peserta didik diberi sebuah multimedia pembelajaran matematika model tutorial berbasis Problem Based Learning pada materi aritmatika sosial. Dalam multimedia pembelajaran pegangan peserta didik terdiri dari beberapa langkah pembelajaran, yang sesuai dengan Problem Based Learning.

\section{Evaluation}

Tahap evaluasi dilakukan setelah semua pembelajaran dilaksanakan pada kelas sesungguhnya dengan tujuan untuk mengukur kompetensi akhir dari tujuan pembelajaran yang ingin dicapai. Hasil dari evaluasi akan dijadikan umpan balik untuk melihat keefektivan multimedia pembelajaran yang 
telah digunakan untuk pembelajaran di kelas sesungguhnya.

Evaluasi dilakukan dengan angket untuk mengetahui persepsi peserta didik dan tes setelah selesai proses pembelajaran. Dari evaluasi tersebut diperoleh hasil berupa multimedia pembelajaran yang dikatakan efektif jika media dipersepsikan secara positif oleh peserta didik dan tujuan dari pengembangan multimedia pembelajaran ini tercapai.

Sebelum tes dilakukan, instrumen tes untuk mengukur kemampuan peserta didik divalidasi kepada ahli untuk mendapatkan soal yang valid dan dapat digunakan dalam mengukur kemampuan peserta didik. Setelah divalidasi dan dinyatakan valid, instrumen tersebut digunakan saat pre-test dan post-test. Pre-test dilaksanakan sebelum pembelajaran menggunakan multimedia dilaksanakan. Sedangkan post-test dilakukan setelah pembelajaran menggunakan multimedia pada materi aritmatika sosial telah dilaksanakan.

Kemudian hasil pre-test dan post-test dianalisis dengan pedoman penskoran yang juga telah divalidasi oleh ahli sebelumnya. Skor maksimal untuk tiap peserta didik yaitu 100. Adapun rentang skor hasil pre-test dan post-test dikembangkan berdasarkan penelitian Sutrimo (2019) dengan sedikit motivasi.

Berdasarkan data hasil pengolahan nilai pre-test dan post-test pada lampiran 19 diperoleh rata-rata pre-test sebesar 57.77 dan rata-rata post-test sebesar 80.41 . Selanjutnya data pre-test dan post-test akan dilakukan uji normalitas untuk mengetahui data atau nilai berdistribusi normal atau tidak. Berikut data hasil uji normalitas pada pre-test dan post-test pada tabel 1.

Tabel 1. Data Hasil Uji Normalitas

Tests of Normality

\begin{tabular}{|l|r|r|r|r|r|r|}
\hline & \multicolumn{3}{|c|}{ Kolmogorov-Smirnov $^{\mathrm{a}}$} & \multicolumn{3}{c|}{ Shapiro-Wilk } \\
\cline { 2 - 7 } & Statistic & \multicolumn{1}{c|}{ Df } & \multicolumn{1}{c|}{ Sig. } & Statistic & \multicolumn{1}{c|}{ df } & \multicolumn{1}{c|}{ Sig. } \\
\hline Pretes & .146 & 36 & .051 & .960 & 36 & .222 \\
Postes & .145 & 36 & .053 & .945 & 36 & .073 \\
\hline
\end{tabular}

Berdasarkan data hasil pengolahan nilai pre-test dan post-test dengan menggunakan uji normalitas diperoleh nilai sig $>0.05$ yang artinya data berdistribusi normal. Selanjutnya data pre-test dan post-test akan dilakukan uji homogenitas untuk melihat bahwa dua atau lebih kelompok data berasal dari populasi yang memiliki variansi yang sama. Data hasil uji homogenitas pada pre-test dan pos-test disajikan pada tabel 2 berikut:

Tabel 2. Data Hasil Uji Homogenitas

Test of Homogeneity of Variances

Hasil Belajar Matematika

\begin{tabular}{|c|c|c|c|}
\hline Levene Statistic & df1 & $\mathrm{df} 2$ & Sig. \\
\hline 3.179 & 1 & 70 & .079 \\
\hline
\end{tabular}


Berdasarkan data hasil pengolahan nilai pre-test dan post-test dengan menggunakan uji homogenitas diperoleh nilai sig sebesar $0.079>0.05$ menunjukkan bahwa data data pre-test dan posttest homogen. Selanjutnya data pre-test dan post-test akan dilakukan uji N-gain untuk mengetahui peningkatan hasil belajar kognitif siswa setelah diberikan perlakuan berupa penggunaaan multimedia pembelajaran matematika model tutorial berbasis Problem Based Learning pada materi aritmatika sosial. Berikut data hasil uji N-gain pada pre-test dan post-test:

$\mathrm{N}$-gain $=\frac{\text { Nilai } \text { posttest-Nilai } \text { pretest }}{\text { Nilai Maksimum-Nilai pretest }}$

$\mathrm{N}-$ gain $=\frac{2895-2080}{3600-2080}$

$\mathrm{N}$-gain $=0.536$

Berdasarkan data hasil pengolahan nilai pre-test dan post-test dengan menggunakan uji $\mathrm{N}$ gain diperoleh nilai $\mathrm{N}$-gain sebesar 0,536 dan dapat diinterpretasikan bahwa terjadi peningkatan hasil belajar siswa dalam kategori sedang (tabel 3.9). Selanjutnya data pre-test dan post-test akan dilakukan uji $t$ dependent (Paired Sample $t$ Test) untuk melihat adanya pengaruh antara pre-test sebelum pembelajaran menggunakan multimedia pembelajaran matematika berbasis Problem Based Learning dengan setelah menggunakan multimedia pembelajaran matematika berbasis Problem Based Learning. Berikut data hasil uji $t$ dependent (Paired Sample $t$ Test) pada pre-test dan post-test:

Tabel 3. Data Hasil Uji $t$ dependent (Paired Sample t Test)

Paired Samples Test

\begin{tabular}{|c|c|c|c|c|c|c|c|c|}
\hline & \multicolumn{5}{|c|}{ Paired Differences } & $\mathrm{t}$ & df & Sig. (2-tailed) \\
\hline & Mean & $\begin{array}{c}\text { Std. } \\
\text { Deviation }\end{array}$ & $\begin{array}{l}\text { Std. } \\
\text { Error } \\
\text { Mean }\end{array}$ & $\begin{array}{c}95 \% \text { Conf } \\
\text { Interval } \\
\text { Differe }\end{array}$ & $\begin{array}{l}\text { idence } \\
\text { f the } \\
\text { nce }\end{array}$ & & & \\
\hline & & & & Lower & Upper & & & \\
\hline $\begin{array}{ll}\text { Pai } & \text { pretes - } \\
\text { r } 1 & \text { postes }\end{array}$ & -22.500 & 13.861 & 2.310 & -27.190 & $\begin{array}{r}- \\
17.809\end{array}$ & -9.739 & 35 & .000 \\
\hline
\end{tabular}

Sumber: Hasil Olahan SPSS

Berdasarkan data hasil pengolahan nilai pre-test dan post-test dengan menggunakan uji $t$ dependent (Paired Sample t Test) diperoleh nilai Sig. (2-tailed) sebesar $0.000<0.05$ maka h0 ditolak berarti ha diterima yang berarti adanya pengaruh penggunaan multimedia pembelajaran matematika berbasis Problem Based Learning terhadap kemampuan siswa sebelum dan sesudah menggunakan multimedia.

Untuk hasil analisis data angket persepsi siswa Jika didasarkan pada Kriteria Pengambilan Keputusan Koefisien Korelasi Intraclass (ICC) adalah berada pada kategori "Sedang". Meskipun dalam kategori sedang namun kedua kelompok siswa baik ganjil maupun genap sudah bersepakat bahwa multimedia ini layak digunakan. 
Pengembangan Multimedia Pembelajaran Matematika Model Tutorial Berbasis Problem Based Learning pada Materi Aritmatika Sosial untuk Siswa SMP/MTs, Bj. Nofrian Kurnia, Jefri Marzal, Zurweni

\section{Diskusi}

Beberapa penelitian pengembangan berbasis Problem Based Learning sudah pernah dilakukan sebelumnya. Seperti penelitian yang dilakukan oleh Yustianingsih, R., Syarifuddin, H., \& Yerizon (2017) yaitu melakukan pengembangan perangkat pembelajaran matematika berbasis Problem Based Learning untuk meningkatkan kemampuan pemecahan masalah peserta didik kelas VIII. Dimana dalam penelitiannya tingkat validitas dapat diketahui berdasarkan review ahli materi, review ahli desain, review ahli pendidikan, review oleh ahli praktisi, uji coba perorangan, uji coba kelompok kecil dan uji coba lapangan. Selain itu penelitian yang dilakukan oleh Indrawati, I., \& Nufus (2018) yaitu melakukan pengembangan modul praktikum kimia berbasis Problem Based Learning untuk siswa kelas XI SMA. Dimana dalam penelitiannya untuk melihat valid atau tidaknya modul dan instrumen yaitu dengan memberikan angket ke pada validator yang meliputi ahli desain, ahli bahasa dan ahli materi.

Menurut Rusdi (2018) dapat disimpulkan bahwa multimedia yang dikembangkan telah valid dan dapat digunakan atau diimplementasikan pada pembelajaran di kelas, setelah mengalami revisi atau perbaikan sesuai saran dan komentar agar multimedia yang dikembangan lebih sesuai dan menarik minat peserta didik. Berdasarkan hal tersebut maka multimedia yang telah peneliti buat dan dilakukan perbaikan berdasarkan saran dan komentar dari tim validasi maka multimedia pembelajaran matematika model tutorial berbasis Problem Based Learning tersebut layak untuk diimplementasikan dan dinyatakan valid.

Penilaian kualitas multimedia yang dikembangkan selanjutnya adalah kepraktisan. Aspek kepraktisan merupakan kriteria kualitas perangkat pembelajaran yang dapat dilihat dari mudahnya guru dan siswa dalam menggunakan perangkat pembelajaran yang dikembangkan Plomp, T., \& Nieveen (1999) dalam mengembangkan perangkat pembelajaran harus disesuaikan dengan harapan dan kebutuhan di lapangan, apabila terdapat kekonsistenan antara kurikulum dengan proses pembelajaran maka perangkat pembelajaran dikatakan praktis jika para responden menyatakan perangkat pembelajaran dapat digunakan dalam pembelajaran yang ditunjukan oleh angket atau kuosioner (apresiasi) oleh guru dan siswa.

Berdasarkan hal tersebut, untuk mengetahui kepraktisan Multimedia yang peneliti buat yaitu dengan memberikan angket berisi penilaian atau tanggapan yang ditujukan kepada guru pengajar matematika kelas VII serta para siswa setelah mengamati Multimedia yang dikembangkan. Hal ini dilakukan saat proses uji coba produk. Dalam proses uji coba, uji coba kelompok kecil, dan uji coba kelompok besar. Hasil yang diperoleh yaitu pada uji coba kelompok kecil dan uji coba kelompok besar juga medapatkan tanggapan yang sangat positif terhadap Multimedia yang dikembangkan.

Beberapa penelitian pengembangan multimedia pembelajaran dengan materi aritmatika sosial sudah pernah dilakukan sebelumnya, namun dengan pendekatan yang berbeda dengan peneliti gunakan, seperti penelitian yang dilakukan oleh Anas, M. A., Soepriyanto, Y., \& Susilaningsih (2019) dalam penelitiannya mengembangkan multimedia pembelajaran matematika menggunakan model 
Tutorial Topologi Jaringan untuk siswa SMK kelas X, dan didapati hasilnya memperlihatkan bahwa model Tutorial diperoleh rata-rata keseluruhan jawaban audien berjumlah 3,2 dari total rata-rata yang diharapkan 4,00. Sehingga diperoleh hasil bahwa multimedia tutorial cukup layak untuk digunakan. Namun, ada siswa yang berkomentar agar aplikasi multimedia tutorial lebih ditingkatkan lagi dalam kejelasan isi dan materi. Berdasarkan hasil tersebut, diperoleh bahwa peningkatan kemampuan matematis peserta didik setelah menggunakan media. Hal ini menunjukkan kesamaan dengan hasil yang peneliti buat yaitu multimedia pembelajaran matematika yang dikembangkan sama-sama efektif dalam pembelajaran.

Berdasarkan hasil analisis dengan penelitian lain tersebut, dapat disimpulkan bahwa pengembangan multimedia pembelajaran dengan pendekatan lain juga dapat meningkatkan kemampuan siswa namun perlu ditambah unsur yang lain dalam pengembangan multimedia pembelajaran matematika agar multimedia pembelajaran lebih menarik, salah satunya dengan menghubungkan pembelajaran dengan kehidupan nyata dengan menggunakan model Problem Based Learning dalam pembelajaran sehingga siswa akan terbiasa karena dihubungkan dengan masalah dalam kehidupan nyata.

\section{KESIMPULAN}

Berdasarkan hasil penelitian dan pembahasan tentang pengembangan multimedia pembelajaran matematika model tutorial berbasis Problem Based Learning, maka dapat disimpulkan bahwa:

1. Proses pengembangan multimedia pembelajaran matematika model tutorial berbasis Problem Based Learning menggunakan model ADDIE menurut Lee \& owens yang terdiri dari beberapa tahap, pertama analyze (analisis) yaitu menganalisis pengguna produk yang akan dikembangkan, menganalisis teknologi untuk produk yang akan dikembangkan, menganalisis situasi sekolah dan fasilitasnya, menganalisis spesifikasi mata pelajaran, kelas, program keahlian, KD dan KI pada mata pelajaran tertentu, dan sebagainya yang berkaitan dengan produk yang akan dikembangkan, menganalisis tujuan mata pelajaran yang dipilih untuk dijadikan materi pembelajaran dan menyimpulkan dari berbagai analisis sebelumnya untuk dijadikan media yang akan dikembangkan. kemudian dilanjutkan pada design (desain) yaitu peneliti merancang produk yang akan dikembangkan sesuai dengan apa yang dibutuhkan dengan mengadakan revisi desain, kemudian tahap development (pengembangan) yaitu tahap mengembangkan produk dengan memvalidasi produk kepada ahli materi, ahli desain dan penilaian guru tahapan selanjutnya yaitu implementation (implementasi) dengan melakukan uji coba terhadap produk yang sudah di desain dan di revisi dengan uji coba kelompok kecil (8 orang siswa kelas VIIB SMP Negeri 1 Muaro Jambi), dan uji coba kelompok besar (36 orang siswa kelas VIIA SMP Negeri 1 Muaro Jambi) dilanjutkan dengan menerapkan multimedia yang telah dilakukan uji coba pada kelas VIIA SMP Negeri 1 Muaro Jambi, dan terakhir tahap evaluation (evaluasi), yaitu evaluasi yang berorientasi 
pada kelayakan multimedia yang dikembangkan melalui validasi ahli media, ahli materi serta hasil ujicoba produk.

2. Multimedia pembelajaran matematika model tutorial berbasis Problem Based Learning dinyatakan valid. Kevalidan diperoleh berdasarkan penilaian dari tim validator yaitu validator materi, dan validator desain media. Berdasarkan penilaian tim validator dapat disimpulkan bahwa multimedia yang dikembangkan valid dan layak digunakan berdasarkan perbaikan sesuai saran dan komentar.

3. Multimedia pembelajaran matematika model tutorial berbasis Problem Based Learning dinyatakan praktis. Kepraktisan diperoleh berdasarkan penilaian dan tanggapan dari guru dan peserta didik terhadap multimedia yang digunakan dan hasilnya yaitu guru dan peserta didik memberikan tanggapan positif serta menurut guru dan peserta didik multimedia yang dikembangkan dapat membuat ketertarikan karena menggunakan model tutorial berbasis Problem Based Learning.

4. Multimedia pembelajaran matematika model tutorial berbasis Problem Based Learning dinyatakan efektif. Keefektifan diperoleh berdasarkan produk yang dikembangkan dapat meningkatkan hasil belajar peserta didik dari hasil pre-test dan post-test yang di uji dengan uji Ngain. Setelah dianalisis dengan uji $\mathrm{N}$-gain diperoleh skor 0.536 yaitu dalam kategori sedang dan berdasarkan uji $t$ dependent (Paired Sample T-tes) diperoleh nilai signifikansi (2-tailed) sbesar $0.000<0.05$ sehingga dapat disimpulkan bahwa ada perbedaan rata-rata antara skor pretest dan posttest sehingga multimedia yang dikembangkan sudah efektif.

\section{REFERENSI}

Anas, M. A., Soepriyanto, Y., \& Susilaningsih, S. 2019. "Pengembangan Multimedia Tutorial Topologi Jaringan Untuk Smk Kelas x Teknik Komputer Dan Jaringan.” Jurnal Kajian Teknologi Pendidikan 1(4):307-14.

Branch, R. M. 2009. Instructional Design: The ADDIE Approach (Vol. 722). Springer Science \& Business Media.

Dila, Oki Ratna, and Luvy Sylviana Zanthy. 2020. "Identifikasi Kesulitan Siswa Dalam Menyelesaikan Soal Aritmatika Sosial.” Teorema: Teori Dan Riset Matematika 5(1):17. doi: 10.25157/teorema.v5i1.3036.

Indrawati, I., \& Nufus, K. 2018. "Faktor-Faktor Yang Berhubungan Dengan Kelelahan Kerja Pada Tenaga Kerja Bagian Kandang Di PT Charoen Pokphand Jaya Farm 3 Kecamatan Kuok.” Jurnal Ners 2(1):56-71.

Istikomah, E. 2020. "Model Problem-Based Learning Untuk Meningkatkan Hasil BelajarMatematika Siswa Pada Materi Aritmatika Sosial. AKSIOMATIK: Jurnal Penelitian Pendidikan Dan Pembelajaran Matematika." AKSIOMATIK: Jurnal Penelitian Pendidikan Dan Pembelajaran Matematika 8(1):59-63. 
Lee, W. W., \& Owens, D. L. 2004. "Multimedia-Based Instructional Design: Computer-Based Training, Web-Based Training, Distance Broadcast Training, Performance-Based Solutions.” John Wiley \& Sons, Ltd: England.

Nurnugroho, B. A., Supama, S., \& Zulijanto, A. 2019. "Operator Linear-2 Terbatas Pada Ruang Bernorma-2 Non-Archimedean." Jurnal Fourier 8(2):43-50.

Plomp, T., \& Nieveen, N. 1999. "Prototyping to Reach Product Quality. In Design Approaches and Tools in Education and Training." Springer, Dordrecht 125-35.

Rusdi, M. 2018. Penelitian Desain Dan Pengembangan Kependidikan. Depok: PT Rajagrafindo.

Sutrimo. 2019. "Pengembangan Lembar Kerja Peserta Didik (LKPD) Dengan Pendekatan Inquiry Berbasis Budaya Jambi Untuk Meningkatkan Kemampuan Berpikir Kreatif Matematis." Universitas Jambi.

Yustianingsih, R., Syarifuddin, H., \& Yerizon, Y. 2017. "Pengembangan Perangkat Pembelajaran Matematika Berbasis Problem Based Learning (PBL) Untuk Meningkatkan Kemampuan Pemecahan Masalah Peserta Didik Kelas VIII.” JNPM (Jurnal Nasional Pendidikan Matematika) 1(2):258-74. 